\title{
高温条件がアサリ稚貝の生残に与える影響の定量化
}

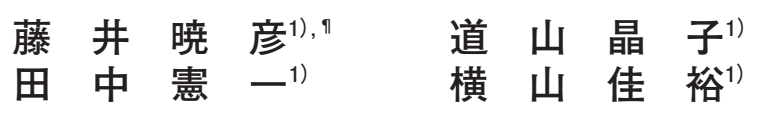

\section{Quantification of Effect of High Temperature on Survival Ability of the Juvenile of Manila Clam}

\author{
Akihiko FUJII ${ }^{1), ~ ", ~ A k i k o ~ M I C H I Y A M A ~}{ }^{1)}$, Ken-ichi TANAKA ${ }^{1)}$ and Yoshihiro YOKOYAMA ${ }^{1)}$ \\ 1) Kyushu Environmental Evaluation Association, Matsukadai 1-10-1, Higashi-ku, Fukuoka 813-0004, Japan
}

\section{Abstract}

The ground temperature of the Wajiro tidal flat rises up to $40{ }^{\circ} \mathrm{C}$ in summer, and this high-temperature condition becomes one of the mortality factors of Manila clams. It was noted in a previous study that Manila clams die at $35^{\circ} \mathrm{C}$ or higher, but there are few findings on the percentage of surviving individuals being related to the exposure time to a high-temperature condition. Hence, we carried out a high-temperature exposure experiment of clams, and formulated a survival rate as a function of temperature and exposure time. The formula derived from the experiment in the laboratory and the observation results of temperature and density of clams in the field was indicated the possibility that high-temperature condition was one of the survival factors of clams. It was considered to be valuable as a formula to quantitatively estimate the decrease in a clam population in relation to temperature and time.

Keywords: Manila clam; Juvenile; High-temperature condition; Survival rate; Quantification

\section{1.はじめに}

アサリは，我が国の主要な水産資源であるとともに， 潮干狩りの対象, 鳥の餌資源としても重要である ${ }^{1)} 。 1980$ 年代半ばから 1990 年代にかけて, 全国各地の干潟や浅海 域では, アサリ資源の減少が報告され, その要因として 埋立・干拓等による生息地の喪失のほか, 乱獲, 食害, 環境悪化等が挙げられている1, 2)。

我々が山口湾や博多湾のアサリ資源の動態を調査した 結果 ${ }^{3,4)}$ によると, 食害や乱獲 (人による取り出し), 冬 季に強くなる波浪とともに, 夏季の干潟の高温条件が資 源の減少要因となっていた。2009 年 6 月〜 11 月に実施 した喨長 $0.4 \sim 1 \mathrm{~mm}$ 程度の着底稚貝の密度変化と干潟温 度を毎時測定した結果 ${ }^{3)}$ では, 干潟温度が $35{ }^{\circ} \mathrm{C}$ を超えな い低地盤域（冠水率 $98 \%$ ）では着底稚貝の初期生残率が 約 $11 \%$ に対し, 温度が約 $38{ }^{\circ} \mathrm{C}$ まで上昇する高地盤域（冠 水率 $64 \%$ ）では生残率が $2 \%$ と低く, 干潟に加入した直 後の着底稚貝では高温条件が生残に影響していると考え られた。この高温条件が干潟等の野外のアサリ生息場で 起こる原因は, 干潮時に干潟底質が日射で暖められるこ とによるものであり, 高温となりやすい高地盤域では食 害や波浪などとともに高温条件がアサリの主な減少要因 になっていると推定される。

このような高温度とアサリ個体の斃死との関連につい
ては，これまでにも成貝や稚貝の耐性実験の結果が報告 されており，その䦨值は概ね $35 \sim 40{ }^{\circ} \mathrm{C}$ とれている ${ }^{6 \sim 8)}$ 。 しかし，これら報告は，閯值の特定に留まり，高温に暴 露されたアサリが時間の経過とともに，どの程度の割合 で生残するかを明らかにした報告はない。このため，野 外の干潟等における高温条件がアサリ資源をどの程度減 耗させているかを定量的に再現することができず，高温 への対策の有効性も定量的に評価することが難しい。

本研究では, 高温条件によるアサリ資源の減耗の程度 を評価するため，アサリ稚貝を用いた高温暴露実験を行 い, その結果を再現する温度とアサリ生残率との関係を 定量化することを目的とした。

\section{2. 方法}

\section{1 高温暴露実験}

高温暴露の方法は, 温度設定した水槽に試験個体を入 れた容器を浮かべる方法とした（図 1)。水槽（縦 $21 \mathrm{~cm}$ $\times$ 横 $28 \mathrm{~cm} \times$ 高さ $10 \mathrm{~cm}$ ) の深さ $5 \mathrm{~cm}$ まで海水を満た し, サーモスタットに接続したヒーターで設定温度まで 加温し, 緩やかなエアレーションで水を攪拌させた。こ の水槽に, 海水を深さ $1 \mathrm{~cm}$ ほど入れたアルミ製の容器 （直径 $6.5 \mathrm{~cm} \times$ 深さ $3 \mathrm{~cm}$ ）に実験個体（アサリ稚貝）を 10 個体以上（10～21 個体，平均 14 個体）収容したセッ トを，6セット浮かべた。アルミ容器を浮かべた時点を

1 ）一般財団法人九州環境管理協会 $=813-0004$ 福岡市東区松香台 1-10-1

凤 連絡先 : fujii@keea.or.jp 


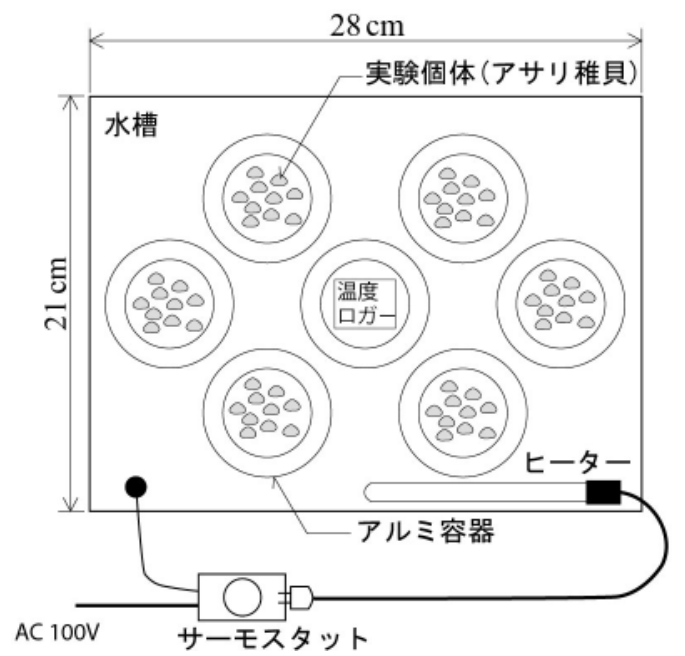

図 1 高温暴露実験装置の模式図

試験開始とし, 同じアルミ製容器に入れた温度ロガーで 暴露温度を 5 分間隔で自動記録した。

暴露実験の温度は，アサリ成貝の成長が最も良いとさ れる $25{ }^{\circ} \mathrm{C}^{7)}$ と, 成長の上限值とされる $30{ }^{\circ} \mathrm{C}^{9)}$ から数時 間で斃死する温度の $40{ }^{\circ} \mathrm{C}^{6,7)}$ までを $2{ }^{\circ} \mathrm{C}$ 刻みで設定する

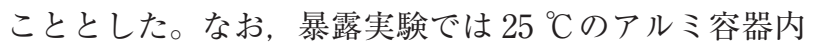

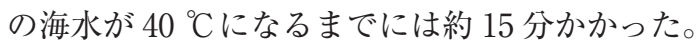

実験に用いたアサリ稚貝は 2013 年 5 月に種苗生産され た個体を譲り受け, ダウンウェリング法により海水を循 環させた容器内で, 種苗用の植物プランクトンを慨とし て与えながら $25{ }^{\circ} \mathrm{C}$ の海水中で約 1 週間飼育した。暴露 実験中は，無給餌で実験を行い，1 日内で実験を完了さ せた。

試験に用いたアサリの殼長は, 平均 $1.1 \mathrm{~mm}$ (標準偏 差 $0.25 \mathrm{~mm}, 63$ 個体測定）であり,これは浮遊幼生が着 底して 1 カ月ほど成長したと見積もられる大きさ10) であ った。

実験時間は, 日中の干潮時に温度が上昇することを想 定した 8 時間までとし, 開始から $1 ， 2 ， 3 ， 4 ， 6 ， 8$ 時間 後にアルミ容器のセットをひとつずつ取り出し, すみや かに容器を $25{ }^{\circ} \mathrm{C}$ の水槽内に戻した後, 実体顕微鏡下で 両殼の隙間に針を差し込み, 殼の開閉に対する活力があ るか・ないか（反射的に閉じるか・閉じないか）で生存・ 死亡を判断し，下式に基づき生残率を求めた。

\section{生残率 $=$ 生存個体数 $/$ 収容個体数}

\section{2 温度と暴露時間, 生残率の定式化}

高温暴露実験で得られた各温度における生残率と暴露 時間との関係から，アサリ稚貝の生残率を温度と時間の 関数とする定式化を試みた。

定式化では，各温度の生残率の経時変化に近似する回 帰式を求め, この回帰式の傾き（速度定数）を温度の関 数とすることで, 生残率を温度と時間の関数とすること を試みた。この定式化した関数の再現性は, 高温暴露実 験との整合と, 過去に野外の干潟で着底稚貝と温度を調 查した結果 ${ }^{3)}$ を用いて検証した。

2.3 野外における干潟温度とアサリ稚貝密度の観測 2009 年 6 月 8 日〜 11 月 3 日にかけて, 博多湾和白干 潟の高地盤域（地盤高 : $+0.7 \mathrm{~m}$ (DL), 干出率 : $22 \%$,
大潮期の最長干出時間 : 約 5 時間), 低地盤域（地盤高： $+0.25 \mathrm{~m}$ (DL)，同干出率 : $2 \%$, 同干出時間 : 約 1.5 時 間）において干潟温度を観測した。なお，干出率は時間 あたりの干出割合である。観測位置は着底稚貝の分布位 置と推定される干潟表面直下とし，ロガー（HOBO 社 TidbiT，大きさ：直径 $30 \mathrm{~mm} \times$ 厚さ $17 \mathrm{~mm}$ ）の表面が 干潟表面となるように埋設して 1 時間ごとの温度を連続 記録した。

アサリ稚貝の調查は, 2009 年 6 月 7 日〜 8 月 23 日に かけて約 2 週間間隔で計 6 回行った。直径 $7 \mathrm{~cm}$ のアク リルパイプを用いて高地盤域・低地盤域のそれぞれ 3 力 所で底泥を採取し，その中に含まれるアサリ稚貝の個体 数を殼長サイズ別 $(0.2 \sim 0.4 \mathrm{~mm}, 0.4 \sim 0.9 \mathrm{~mm}, 0.9 \mathrm{~mm}$ 以上）に実体顕微鏡下で計数した。

\section{3. 結果および考察}

3. 1 高温に暴露されたアサリ稚貝の生残率の経時変化 14 回の各実験における測定温度を表 1 に示す。サーモ スタットの設定温度と水槽内で実測した温度には若干の 差がみられたが, 各実験中の温度変動はほぼ $1{ }^{\circ} \mathrm{C}$ 以内と 小さく，表中右列に示す温度を計算に適用した。

なお, $13 \cdot 14$ 回目の $40{ }^{\circ} \mathrm{C}$ 実験では, 12 回目 $\left(40{ }^{\circ} \mathrm{C}\right.$ の 1 回目）の実験により 3 時間以内で実験個体のほぼ全 数が斃死することがわかっていたため, 実験時間を 3 時 間までと短くし，実験開始から $0.5 ， 1 ， 1.5 ， 2 ， 3$ 時間後 の個体の生残を確認した。

表 1 に示した暴露実験における 1〜8時間のアサリ稚貝 の生残率をみると, $24 \sim 35{ }^{\circ} \mathrm{C}$ までの生残率は, ほぼ 1 で あり，アサリ稚貝は $35{ }^{\circ} \mathrm{C}$ までであれば， 8 時間以内では

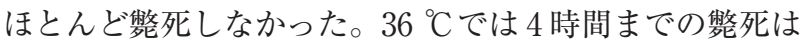
わずかで各実験回の生残率も 0.83 以上と高かったが, 6 時間後には斃死個体が増えて生残率は 0.68〜 1.0 (平均 0.81）に低下し，8時間後には概ね半数が獘死して生残率 は $0.29 \sim 0.81$ (平均 0.51 ） となった。 $38{ }^{\circ} \mathrm{Cでは} 2$ 時間後 から斃死個体が多くなり, 8 時間後には生残率がほぼ 0

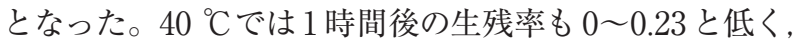
2 時間後にはほぼ生残率が 0 となった。

35，36，38，40 ${ }^{\circ} \mathrm{C}$ の生残率をそれぞれ平均し, 暴露時 間との関係を求めた（図 2)。

$35{ }^{\circ} \mathrm{C}$ では, 上述のとおり 8 時間での斃死はほとんど起 こらず生残率は 1 で一定である。 $36{ }^{\circ} \mathrm{C}$ では 4 時間後か ら, $38{ }^{\circ} \mathrm{C}$ では 1 時間後から斃死が起こり, その後は時間 の経過とともに生残率が減少した。 $40{ }^{\circ} \mathrm{Cではすみやかに}$ 獘死が起こり，1 時間後に生残率は 0 に近づき, 2 時間後 にほぼ 0 となった。

この高温暴露実験の結果から，36～ $38{ }^{\circ} \mathrm{C}$ では死亡する までに数時間の耐性を持ち, その後, 高温の海水に暴露 され続けると次第に斃死個体が増加することが明らかと

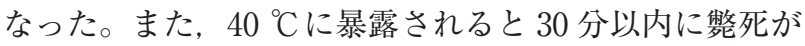
起こり，2〜3 時間でほぼ全数が整死することがわかった。

\section{2 温度に関するアサリ生残率の定式化}

上記（図 2）の高温暴露実験の結果に基づき，高温暴 露されたアサリ生残率を温度の関数とすることを試みた。 本実験では, $36{ }^{\circ} \mathrm{C}$ 以上の高温に暴露されると, それぞれ $36{ }^{\circ} \mathrm{C}$ では 4 8 時間にかけて, $38{ }^{\circ} \mathrm{C}$ では $1 \sim 3$ 時間にか

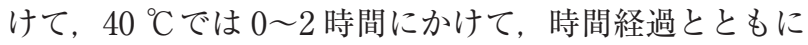


表 1 実験水槽内の温度の測定值と計算に適用した温度, 生残率

\begin{tabular}{|c|c|c|c|c|c|c|c|c|c|}
\hline \multirow{2}{*}{ 実験回 } & \multirow{2}{*}{$\begin{array}{c}\text { 測定温度 }\left({ }^{\circ} \mathrm{C}\right) \\
\text { 平均 } \pm \text { 標準偏差 }\end{array}$} & \multirow{2}{*}{$\begin{array}{c}\text { 計算に適用した } \\
\text { 温度 }\left({ }^{\circ} \mathrm{C}\right)\end{array}$} & \multirow{2}{*}{$\begin{array}{l}\text { 実験時間 } \\
\text { (時間) }\end{array}$} & \multicolumn{6}{|c|}{ 各暴露時間 (時間) における生残率 } \\
\hline & & & & 1 & 2 & 3 & 4 & 6 & 8 \\
\hline 1 & $24.3 \pm 0.6$ & 24 & 8 & 1.00 & 1.00 & 1.00 & 1.00 & 1.00 & 1.00 \\
\hline 2 & $30.6 \pm 0.3$ & 30 & 8 & 1.00 & 0.92 & 1.00 & 1.00 & 1.00 & 1.00 \\
\hline 3 & $32.3 \pm 0.3$ & 32 & 8 & 1.00 & 0.91 & 1.00 & 1.00 & 1.00 & 1.00 \\
\hline 4 & $34.8 \pm 0.3$ & \multirow{2}{*}{35} & 8 & 1.00 & 1.00 & 1.00 & 0.91 & 1.00 & 1.00 \\
\hline 5 & $34.8 \pm 0.3$ & & 8 & 1.00 & 1.00 & 1.00 & 1.00 & 1.00 & 1.00 \\
\hline 6 & $36.3 \pm 0.2$ & \multirow{4}{*}{36} & 8 & 1.00 & 0.93 & 1.00 & 1.00 & 1.00 & 0.38 \\
\hline 7 & $36.4 \pm 0.3$ & & 8 & 0.90 & 1.00 & 1.00 & 1.00 & 0.68 & 0.81 \\
\hline 8 & $36.4 \pm 0.2$ & & 8 & 1.00 & 1.00 & 1.00 & 0.90 & 0.70 & 0.29 \\
\hline 9 & $35.9 \pm 0.2$ & & 8 & 1.00 & 0.83 & 1.00 & 0.96 & 0.86 & 0.54 \\
\hline 10 & $37.9 \pm 0.2$ & \multirow{2}{*}{38} & 8 & 1.00 & 0.69 & 0.29 & 0.40 & 0.25 & 0.08 \\
\hline 11 & $38.0 \pm 0.3$ & & 8 & 0.95 & 0.81 & 0.85 & 0.62 & 0.39 & 0.05 \\
\hline 12 & $40.7 \pm 0.3$ & \multirow{3}{*}{40} & 8 & 0.23 & 0 & 0.07 & 0 & 0 & 0 \\
\hline 13 & $39.5 \pm 0.2$ & & 3 & 0.05 & 0 & 0.06 & - & - & - \\
\hline 14 & $41.0 \pm 0.3$ & & 3 & 0 & 0 & 0 & - & - & - \\
\hline
\end{tabular}

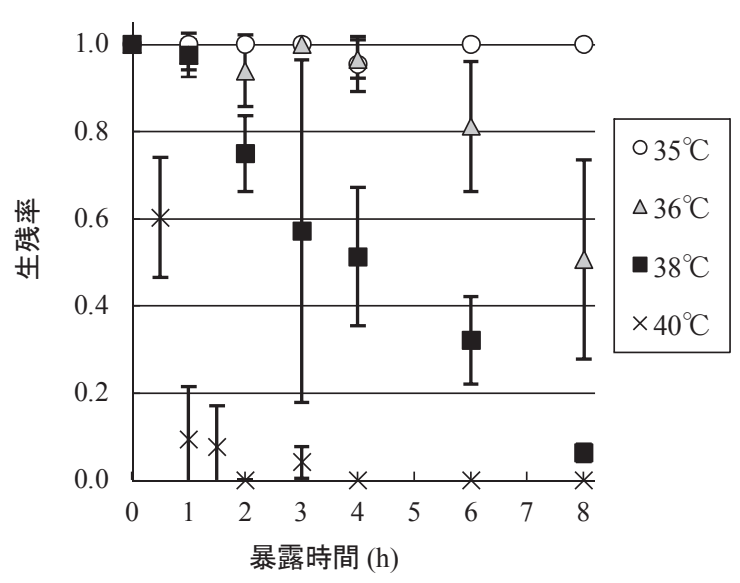

図 $235,36,38,40{ }^{\circ} \mathrm{C}$ の生残率の経時変化：記号は平均值, 縦線は標準偏差

生残率の減少の程度が大きくなる傾向があることから, アサリの生残率 $(S)$ の対数值は時間の 2 乗に比例する と仮定した（式 1)。

$$
S=\exp \left(-k t^{2}\right)
$$

ここで, $S$ : 生残率, $k$ : 死亡速度定数 $\left(\mathrm{h}^{-2}\right), t$ : 時間 $(\mathrm{h})$ である。

高温暴露実験において，アサリが斃死した $36 ， 38,40$ ${ }^{\circ} \mathrm{C}$ の生残率の平均值と暴露時間との関係は図 3 に示すと

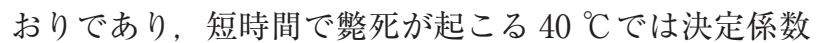
が低いものの, $36,38{ }^{\circ} \mathrm{C}$ の決定係数は高く, 時間の経過 と生残率の低下について概ね良好な相関が得られた。次 いで, 図 3 の回帰式より求めた死亡速度定数 $\left(\mathrm{h}^{-2}\right)(36$ ${ }^{\circ} \mathrm{C}: 9.05 \times 10^{-3}, 38{ }^{\circ} \mathrm{C}$ で $4.10 \times 10^{-2}, 40{ }^{\circ} \mathrm{C}$ で $7.44 \times 10^{-1}$ ) の温度との関係を求めた。算出にあたっては $(2)$ 式に示す 温度係数 $\theta$ を用いた関数形とした。

$$
k=k_{25} \cdot \theta^{T-25}
$$

ここで, $k_{25}$ : 温度 $25^{\circ} \mathrm{C}$ の死亡速度定数 $\left(\mathrm{h}^{-2}\right), \theta$ : 温度

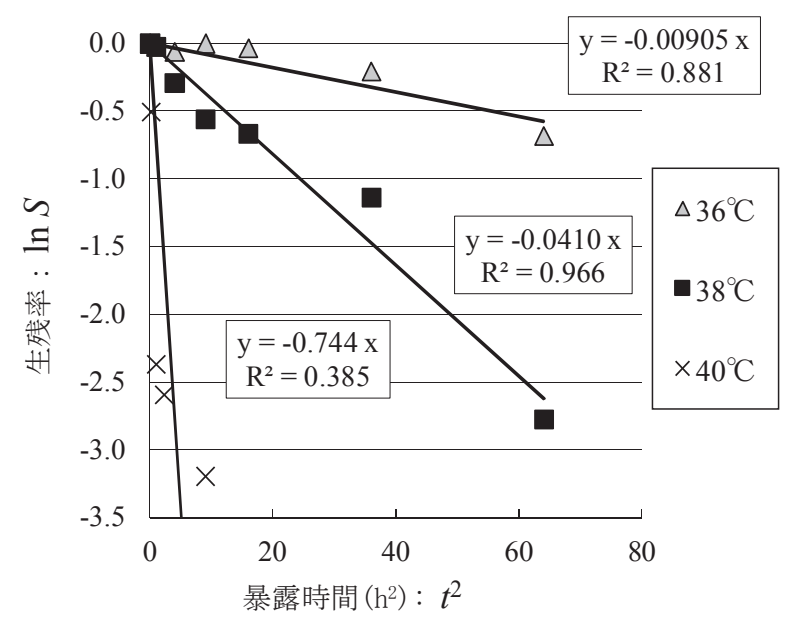

図 3 暴露時間と生残率の関係

係数, $T$ : 温度 $\left({ }^{\circ} \mathrm{C}\right)$ である。なお, 温度係数の基準と した $25^{\circ} \mathrm{C}$ の温度とは, アサリの成長に最も適したとさ れる温度7,11)である。

(2) 式の両辺の対数をとって整理すると，(3) 式となる。

$$
\begin{aligned}
\log k & =\log k_{25}+(T-25) \log \theta \\
& =T \cdot \log \theta+\log k_{25}-25 \cdot \log \theta
\end{aligned}
$$

これより, 横軸を $T$, 縦軸を $\log k$ とした温度と死亡速 度定数との散布図において, その回帰式の傾きが $\log \theta$, 切片が $\log \mathrm{k} 25-25 \cdot \log \theta$ となる。散布図（図4）より，傾 きは 0.479 , 切片は-19.4が得られ, これを解いて $\theta=3.01$, $k_{25}=3.89 \cdot 10^{-8}$ が求まる。(1) 式・(2) 式に(3) 式の解を与 えると, 高温の海水に暴露されるアサリの生残率は, 温 度と時間の関数として(4)式で表現される。

$$
\begin{aligned}
S & =\exp \left(-k t^{2}\right) \\
& =\exp \left[-\left(3.89 \times 10^{-8}\right) \cdot(3.01)^{T-25} \cdot t^{2}\right]
\end{aligned}
$$

図 2 に示した高温暴露実験における生残率の実験值と， 


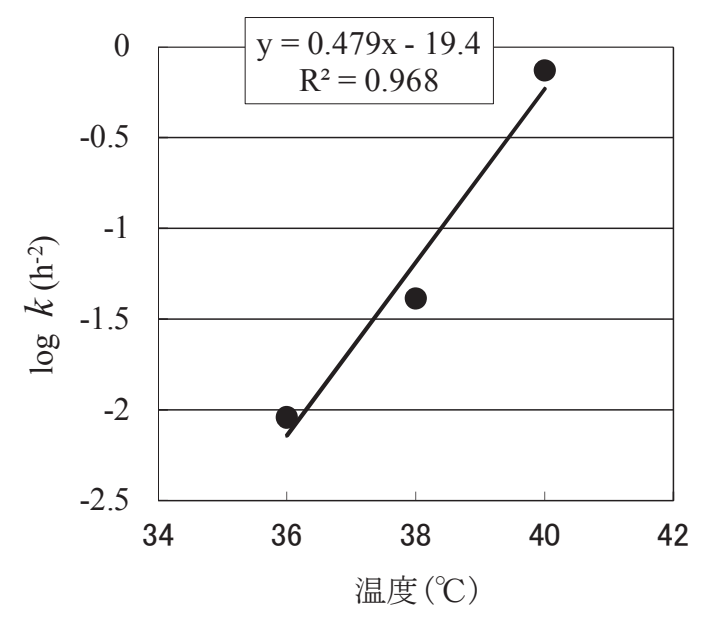

図 4 温度と死亡速度定数の関係

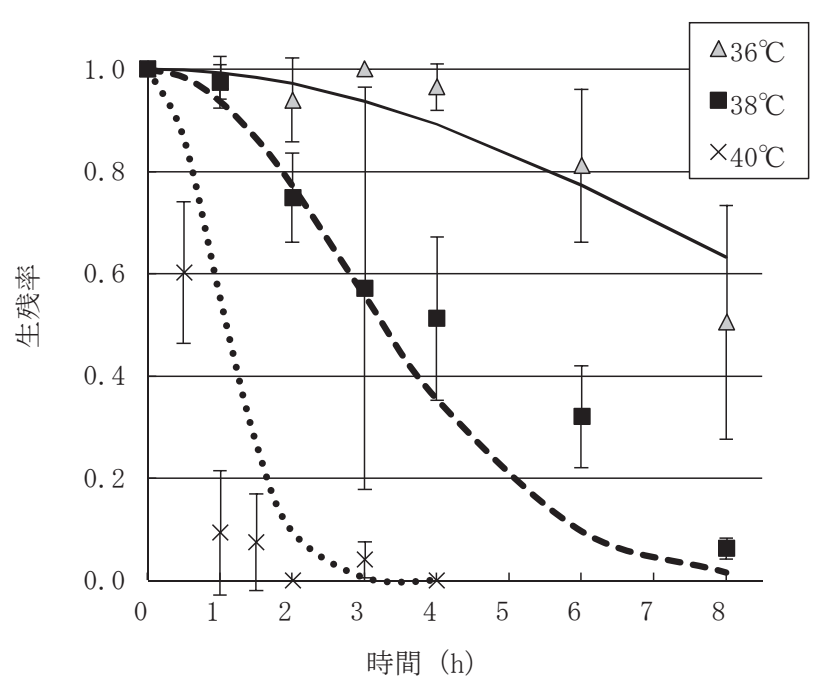

図 5 生残率の実験值と計算值：実験值を示す記号と縦線は 図 2 に同じ, 曲線 $\left(36{ }^{\circ} \mathrm{C}\right.$ : 実線, $38{ }^{\circ} \mathrm{C}$ : 破線, $40{ }^{\circ} \mathrm{C}$ : 点線）は計算值

（4）式に基づき算出した生残率の計算值を図 5 に示す。 40 ${ }^{\circ} \mathrm{C}$ の時には, 計算值よりも実験值のほうが早期に生残率 の低下がみられるなど，計算值と実験值の間には差があ

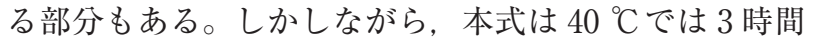
以内の短時間で生残率が著しく低下してほほ全数が䎡死 し, 36〜 $38{ }^{\circ} \mathrm{C}$ では時間経過とともに徐々に生残率が低下 していく状況を表現しており, 高温暴露による生残率の 低下を温度と時間の関数として定式化できていると考え られる。

3. 3 野外における高温条件が稚貝の生残に与える影響 2009 年に観測した高地盤域, 低地盤域の干潟温度を図 6 に示す。干出時間の長い高地盤域では 6 月から $35{ }^{\circ} \mathrm{C}$ 超え始め, 8 月には頻繁に $35{ }^{\circ} \mathrm{C}$ 超えていた。一方, ほ とんど干出しない低地盤域では, $35{ }^{\circ} \mathrm{C}$ を超えることはな かった。

温度一生残率の推定式（(4) 式）に基づき, 高地盤域で 頻繁に $35{ }^{\circ} \mathrm{C}$ を超えていた 2009 年 8 月の生残率を低地盤 域とともに算出した（図 7)。図 7 に示す温度・生残率は 1 時間值であり, 温度の 1 時間值を(4) 式に代入して生残

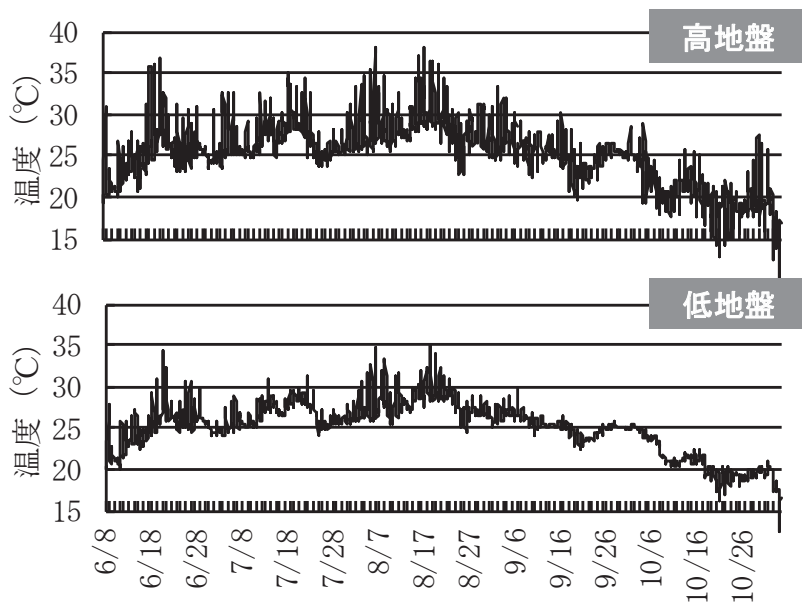

図 6 和白干潟に扮ける干潟表面温度の測定值 (2009 年 6 月 8 日〜 11 月 3 日）
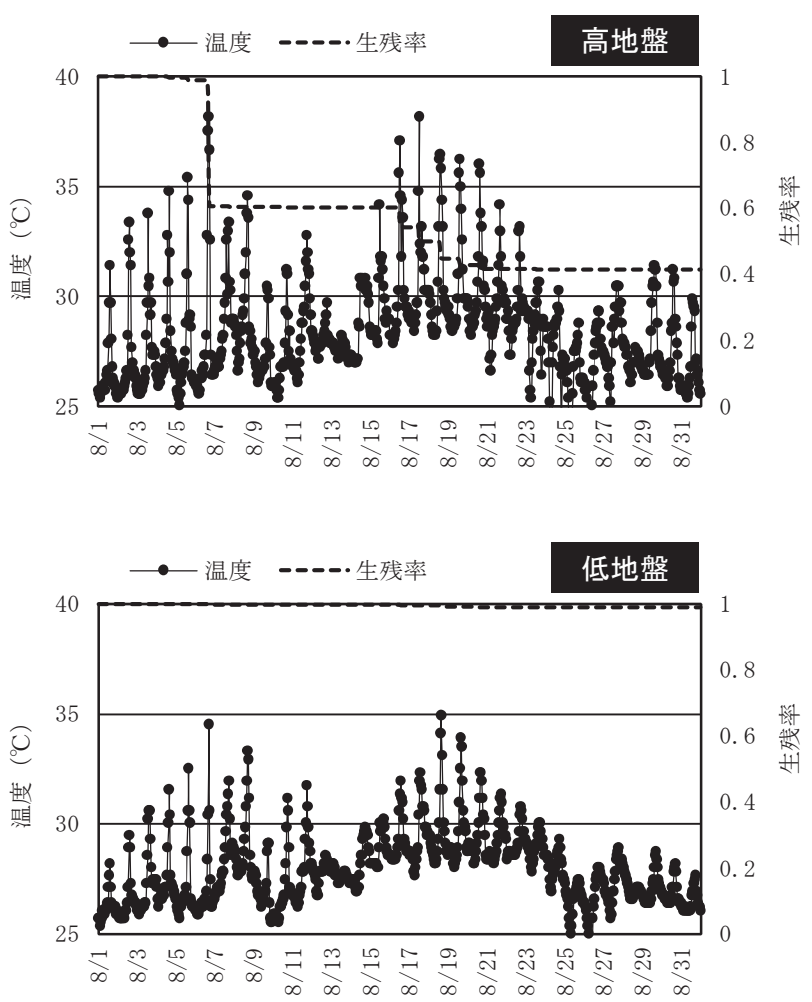

図 7 高地盤・低地盤域の温度測定值で算出した生残率の経 時変化 (2009 年 8 月)

率の值を求めた。 8 月の高地盤域における温度が，6日に 3 時間と 16 日〜 20 日に連日 $1 \sim 3$ 時間ほど $35{ }^{\circ} \mathrm{C}$ を超え たことにより，生残率は 0.4 近くまで低下し，この期間 中にアサリの 5 割以上が高温により獘死すると試算され た。一方， $35{ }^{\circ} \mathrm{C}$ ほとんど超えなかった低地盤域の生残 率は 8 月の期間中にほぼ 1 を維持し, 温度に起因した死 亡は起こらないと計算された。

2009 年 6 月 8 月にかけての着底稚貝の個体数密度の 経時変化を図 8 に示す。アサリ稚貝は殼長 $0.2 \sim 0.25 \mathrm{~mm}$ で干潟に着底し, 約 1 力月で㪍長 $1 \mathrm{~mm}$ になる ${ }^{9,11}$ 。殼 長の大きさ別に個体数密度の変化をみると, 高地盤域で は着底直後の $0.4 \mathrm{~mm}$ 未満の個体は分布しているが, 0.4 $\mathrm{mm}$ 以上の個体は 6 月 7 日を除いてほとんど出現しなか 

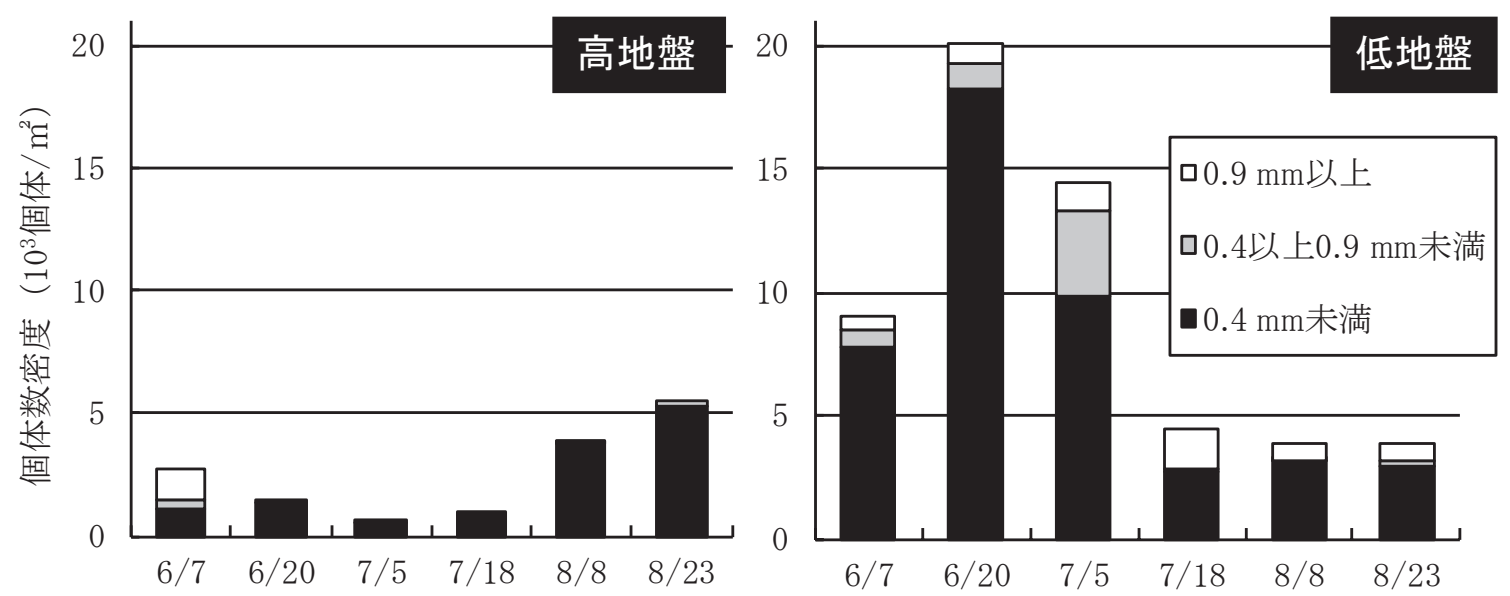

図 8 高地盤・低地盤域における着底稚貝の個体数密度の経時変化（2009 年）

った。一方, 低地盤域では, $0.4 \mathrm{~mm}$ 以上の稚貝が期間 を通して出現しており, $0.9 \mathrm{~mm}$ 以上の個体も出現して いた。この高地盤域と低地盤域に扔けるアサリ稚貝の生 残を比べると, 低地盤域では着底直後の稚貝が時間経過 とともに数を減らしながらも一定数が生残するが, 高地 盤域では着底直後の稚貝は出現するものの, 時間経過と ともにそのほとんどが死亡していると言える。

野外の干潟では, 高温条件以外にも, エイ類や巻貝類, カニ類, ヒトデ類等の食害生物による捕食 ${ }^{9}$, 潮流や波 浪等の物理的な攪乱による影響 14,15$)$ などが減耗要因とさ れ, 和白干潟に抢いても複数の要因がアサリ資源の減耗 に関わっていると考えられる。低地盤域・高地盤域とも に, 着底直後の稚貝が時間経過とともに密度を低下させ ている原因は, これら複数の要因が影響していると考え られるが，その要因の特定と各要因が稚貝の生残に影響 している程度は明らかでない。一方で, 高地盤域のみで 着底直後の稚貝のほとんどが時間経過とともに死亡して いることは, 夏季の高地盤域で生じる高温条件がアサリ 稚貝の減耗要因のひとつになっている可能性を示すもの である。本研究で求めたアサリ稚貝の生残率と温度, 暴 露時間の関係式と現地の実測值から，2009 年 8 月には高 地盤域で高温によって半数以上が死亡すると計算された （図 7)。野外の高地盤域における観測によると稚貝のほ とんどが死亡していることと, 室内実験に基づく生残率 の計算值によると半数以上が死亡するとの間には, 生残 の程度に差がある。この程度の差の原因として, 室内実 験と野外の生息条件の差, 例えば実験では高温暴露を冠 水条件で与えているが, 野外では高温暴露が干出条件で 起こること, あるいは室内実験は 1 回の高温暴露による ものであるが, 野外では連日, 高温暴露が生じることが あり, 生残への影響が蓄積されている可能性などが考え られる。

このように，野外におけるアサリ稚貝の生残には複数 の要因が関わっている中で, $35{ }^{\circ} \mathrm{C}$ 以上の高温条件が生じ る生息域では高温により稚貝が死亡しており, 温度の観 測值および室内実験に基づく生残率の推定值によると半 数以上が死亡すると試算されることから, 高温条件はア サリ稚貝の減耗に対して一定の影響を及ぼす生残要因の ひとつになっている可能性が高い。本研究の結果から,
室内実験に基づいた温度と暴露時間を定式化した生残率 の推定式は, 高温条件に対するアサリ稚貝の生残・減耗 の状況を定量的に推定する上で有効であると考えられる。

\section{4. まとめ}

本研究の結果, アサリ稚貝の高温条件に抢ける生残状 況と, 温度と生残率との定量化に関して, 以下のことが 明らかとなった。

・高温暴露実験の結果, 稚貝の整死は $36{ }^{\circ} \mathrm{C}$ 以上で起こ

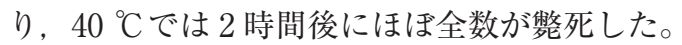

- 実験に基づく温度 - 生残率の関係から, 死亡速度定数 を温度の関数とした生残率の推定式を得ることができ た。

・温度一生残率の推定式を適用して, 野外の干潟に扔け る高温条件がアサリ稚貝の生残に影響する程度を求め た結果， 2009 年の高温条件では 5 割以上が敖死すると 試算され, 高温条件は生残要因のひとつであり, 一定 割合の稚貝が高温により減耗している可能性が示され た。

\section{5. おわりに}

本研究では, 室内における高温暴露実験に基づき, 温 度一生残率の推定式を得ることができた。今後は, 野外 におけるアサリ資源の変動と温度との関係を調査し, 本 推定式の再現性を確認するとともに, 高温条件以外の生 残要因, さらには複数の要因が同時に生じた場合の生残 への影響についても明らかにしていく必要がある。

また，推定式の前提となる暴露実験では，1日（8時 間）の短期暴露における生残を確かめたものであり，野 外の夏季のように高温化が連日生じた時の生残状況は未 検証である。この高温条件を繰り返した場合の生残状況 についても検証し，推定式の精緻化を図る必要がある。

\section{謝 辞}

本研究は, 筆者らが所属する社内研究会において調査・ 検討を重ねてきたものであり, 本研究会の社内メンバー や外部から参加いただいている九州大学大学院生物資源 環境科学府の田畑俊範氏には多くの助言をいただいた。 また，高温暴露実験におけるアサリ稚貝の飼育方法等に 
ついては, 公益社団法人山口県栽培漁業公社の渡邊直氏, 佐藤雅弘氏に貴重な技術・知見をお教えいただいた。こ こに記して感謝の意を表したい。

（原稿受付 2015 年 3 月 19 日） (原稿受理 2016 年 2 月 29 日)

\section{参 考 文 献}

1 ）アサリ資源全国協議会企画会議, 水産庁増殖推進部, 独立行政 法人水産総合研究センター, 2009. 提言国産アサリの復活に向け て, $19 \mathrm{p}$.

2 ）松川康夫, 張成年, 片山知史, 神尾光一郎, 2008. 我が国のア サリ漁獲量激滅の要因について. 日本水産学会誌 74, 137-143.

3 ) 藤井暁彦, 道山晶子, 関根雅彦, 2010. 和白干潟に扔ける成 長・生活史を考慮したアサリ資源動態の解明とその保全策. 環境 工学研究論文集 47, 215-222.

4 ）藤井暁彦, 関根雅彦, 尾添紗由美, 萩原淳子, 角野浩二, 2011. 山口湾の自然再生事業におけるアサリ保全策の効果検証と管理モ デルによる資源回復策の検討. 水環境学会誌 34(9)，143-152.

5 ) 藤井暁彦, 関根雅彦, 萩原淳子, 今井剛, 樋口隆哉, 2008. 博 多湾和白干潟に扔けるアサリ保全策の有効性. 環境工学研究論文 集 45, 495-500.

6 ）倉茂英次郎, 1957. アサリの生態研究, 特に環境要素につい
て. 末広恭雄, 大島泰雄, 桧山義夫編, 水産学集成. 東京大学出 版会, 東京, pp.611-655.

7 ) 磯野良介, 喜田潤, 岸田智穂, 1998. アサリの成長と溶存酸素 量に打よぼす高温の影響. 日本水産学会誌 64, 373-376.

8 ）木下秀明, 1985. アサリの卵・浮遊幼生・稚貝の高温耐性. 海 洋生物環境研究所研究報告 (85204), 1-38.

9 ）全国沿岸漁業振興開発協会, 1997. アサリの生態と漁業. 沿岸 漁業整備開発事業増殖場造成計画指針ヒラメ・アサリ編, pp.123-164.

10）今井厚, 大橋裕, 平岡美登里, 山本翠, 1992. アサリ種苗生産 及び増殖試験. 山口県内海水産試験場報告 21, 29-55.

11）鳥羽光晴, 2005 . アサリ. 森勝義編, 水産増養殖システム 3 貝 類 - 甲殼類 - ウ二類 - 藻類. 恒星社厚生閣, 東京, pp.287-298.

12）大隈斉，山口忠則，川原逸朗，伊藤史郎，2004. 有明海湾奥部 におけるアサリ種苗生産に関する研究. 佐賀有明水研報 22 , 55-59.

13）網尾勝, 1982. アサリの増殖について. 日本水産資源保護協会 月報 $217,4-10$.

14）山本正昭，2005．アサリ漁場内の底質環境とその特性．水産総 合研究センター報告 別冊 3 号, 17-25.

15）柿野純, 古畑和哉, 長谷川健一, 1995. 東京湾盤洲干潟におけ る冬季のアサリのへい死要因について. 水産工学 32, 23-32.

\section{[論 文 要 旨]}

夏季に干潟温度が $40{ }^{\circ} \mathrm{C}$ 近くまで高温化する和白干潟では，この温度上昇がアサリの整死要因のひとつと なっている。アサリが $35{ }^{\circ} \mathrm{C}$ 以上になると憼死することは既往の研究においても指摘されているが, 温度と 暴露時間, 生残する個体の割合についての知見はそしい。そこで, 高温暴露実験によりアサリ稚貝の生残率 と温度, 暴露時間との関倸を求め, この生残率を温度と時間の関数として定式化することにより, 高温条件 によるアサリ稚貝の減耗の程度を明らかにした。この式により求めた生残率の推定值と, 野外における高温 条件と稚貝の個体数密度の経時変化から, 野外においても高温条件がアサリ稚貝の減耗要因のひとつとなっ ている可能性が示された。本実験に基づく，一定割合の個体数の減耗を現す温度・暴露時間と生残率の式は, アサリ稚貝の減耗の状況を定量的に推定するものとして有効であると考えられた。

キーワード：アサリ；稚貝；高温条件；生残率；定量化 